\title{
12 Participatory variety selection of improved food barley varieties
}

\author{
Teferi Alem, Wondimu Bayu and \\ Melle Tilahun
}

\section{Introduction}

Barley (Hordeum vulgare) has a long history as a domesticated crop. It was one of the first to be adopted for cultivation and is now produced virtually worldwide (von Bothmer et al., 2003). In Ethiopia, barley is also one of the oldest cultivated crops (Harlan, 1969) and currently it is the fifth most important cereal crop next to teff, maize, wheat and sorghum with total area coverage of over 1 million hectares of land (CSA, 2007). Even though barley is produced on a vast area of land in the country, its productivity has never been above 1.3 t/ha, which is about half the world's average productivity (Mulatu and Lakew, 2006). However, barley is the most desirable crop for food security in the highlands of Ethiopia where soil fertility has been declining as a result of soil erosion and continuous cultivation and other cereal crops do not perform well. Most farmers in the northern highlands of Gondar grow local varieties which have low yielding ability. Because of this, farmers grow barley with wheat as a mixed crop called 'Duragna', and currently the area covered by barley as a sole crop has declined (personal observation). Several improved varieties with their agronomic packages have been developed since barley improvement research began in Ethiopia in the 1950s (Mulatu and Lakew, 2006). However, most of these varieties have not been promoted and utilized by farmers, particularly in this area. Some of the reasons for this low adoption of improved varieties, as mentioned by Yirga et al. (1998), is the traditional top-down research and development process which lacks the participation of the ultimate users, the farmers, as well as the inaccessibility of improved varieties to the farming community. Therefore, the objective was to identify well adapted and high yielder improved food barley varieties with the participation of farmers.

\section{Materials and methods}

The experiment was conducted using nine improved food barley varieties (Shediho, Agegnehu, Yedogit, Estayish, Misrach, Tilla, Setegn, Bentu and 
HB1307) and a farmers' variety during the 2010 main cropping season in the Gumara-Maksegnit watershed area, North Gondar zone. The design was randomized complete block with three replications. Each experimental plot had a total and harvestable area of $12 \mathrm{~m}^{2}(3 \mathrm{~m} \times 4 \mathrm{~m})$ and $6 \mathrm{~m}^{2}(2 \mathrm{~m} \times 3 \mathrm{~m})$ respectively. Seeds were sown in broadcast at a rate of $125 \mathrm{~kg} / \mathrm{ha}$. Fertilizers were also applied in broadcast at rates of $41 / 46 \mathrm{~kg} / \mathrm{ha}$ nitrogen $(\mathrm{N})$ and $\mathrm{P}_{2} \mathrm{O}_{5}$ respectively. $\mathrm{N}$ application was split (half at planting and half at tillering) whereas all the $\mathrm{P}_{2} \mathrm{O}_{5}$ was applied at planting. Weeding was done twice at seedling and before booting stages.

At maturity, farmers were invited to evaluate and select varieties based on morphological plant aspect using their selection criteria. Earliness, number of rows, tillering capacity, plant height, total biomass and grain fullness were the farmers' selection and comparison criteria. Number of days to heading and maturity, plant height, spike length, dry biomass and yield were collected and analysed using the Statistical Analysis System (SAS) (SAS, 2003). Simple correlation was done for grain yield and other traits and Spearman's rank correlation was also carried out to assess the farmers' and researcher's preferences for the varieties based on the grain yield rank. Two replications of data were used for analysis as the data collected from the third replication was unsatisfactory (for some treatments, the grain yield was reduced by half).

\section{Results and discussion}

There were significant differences $(P \leqslant 0.05)$ among food barley varieties in days to maturity, grain yield, plant height and above ground biomass but not for spike length (Table 12.1). However, the improved varieties did not show statistically significant difference over the farmers' variety for any traits except earliness. Plant height ranged from $58.6 \mathrm{~cm}$ (Yedogit) to $92.3 \mathrm{~cm}$ (Shediho) and for above ground biomass, the range was between $7,831 \mathrm{~kg} / \mathrm{ha}$ (Setegn) and $11,829 \mathrm{~kg} / \mathrm{ha}$ (Estayish). The grain yield range was between $1,191.7 \mathrm{~kg} / \mathrm{ha}$ and $2,380.8 \mathrm{~kg} / \mathrm{ha}$ for the varieties Yedogit and Estayish respectively. Varieties were ranked based on earliness and yield advantage; the best performing varieties were Estayish $(2,380.8 \mathrm{~kg} / \mathrm{ha})$, Agegnehu $(2,098.3 \mathrm{~kg} / \mathrm{ha})$, Shediho $(2,045.0 \mathrm{~kg} / \mathrm{ha})$ and HB1307 (1,876.7 kg/ha).

Positive and significant relations were found between grain yield and plant height and between grain yield and biomass yield. But grain yield was negatively and non-significantly related to number of days to maturity (Table 12.2). The positive and significant association result was in line with Budakli and Celik (2012) who found a positive and highly significant correlation between grain yield and plant height in two rowed barley. Positive and highly significant correlations between grain yield and plant height and grain yield and biomass were also reported by Abdollah et al. (2011) in barley lines. In hull-less barley, Drikvand et al. (2011) also found non-significant negative and positive correlations between grain yield and number of days to heading and maturity respectively. 
Table 12.1 Performance of food barley varieties in Gumara-Maksegnit watershed in 2010

\begin{tabular}{llllll}
\hline Variety & $\begin{array}{l}\text { Plant } \\
\text { height } \\
(\mathrm{cm})\end{array}$ & $\begin{array}{l}\text { Spike } \\
\text { length } \\
(\mathrm{cm})\end{array}$ & $\begin{array}{l}\text { Days to } \\
\text { maturity }\end{array}$ & $\begin{array}{l}\text { Above } \\
\text { ground } \\
\text { biomass } \\
(\mathrm{kg} / \mathrm{ha})\end{array}$ & $\begin{array}{l}\text { Grain } \\
\text { yield } \\
(\mathrm{kg} / \mathrm{ha})\end{array}$ \\
\hline Shediho & $92.3^{\mathrm{a} \dagger}$ & 5.1 & $96^{\mathrm{b}}$ & $9163^{\mathrm{b}}$ & $2045.0^{\mathrm{ab}}$ \\
Agegnehu & $82.4^{\mathrm{ac}}$ & 5.6 & $96^{\mathrm{b}}$ & $9496^{\mathrm{ab}}$ & $2098.3^{\mathrm{ab}}$ \\
Yedogit & $58.6^{\mathrm{e}}$ & 5.2 & $99^{\mathrm{b}}$ & $9330^{\mathrm{b}}$ & $1191.7^{\mathrm{c}}$ \\
Estayish & $78.4^{\mathrm{bcd}}$ & 5.9 & $96^{\mathrm{b}}$ & $11829^{\mathrm{a}}$ & $2380.8^{\mathrm{a}}$ \\
Misrach & $76.2^{\mathrm{cd}}$ & 5.1 & $96^{\mathrm{b}}$ & $7997^{\mathrm{b}}$ & $1722.5^{\mathrm{bc}}$ \\
Tilla & $58.4^{\mathrm{e}}$ & 6.5 & $96^{\mathrm{b}}$ & $7830^{\mathrm{b}}$ & $1532.5^{\mathrm{bc}}$ \\
Setegn & $86.8^{\mathrm{ab}}$ & 6.8 & $99^{\mathrm{b}}$ & $7831^{\mathrm{b}}$ & $1626.7^{\mathrm{bc}}$ \\
Bentu & $72.0^{\mathrm{d}}$ & 5.4 & $104^{\mathrm{a}}$ & $7997^{\mathrm{b}}$ & $1493.3^{\mathrm{bc}}$ \\
HB1307 & $84.2^{\mathrm{abc}}$ & 5.4 & $100^{\mathrm{ab}}$ & $9996^{\mathrm{ab}}$ & $1876.7^{\mathrm{ab}}$ \\
Local & $85.4^{\mathrm{abc}}$ & 6.9 & $104^{\mathrm{a}}$ & $9496^{\mathrm{ab}}$ & $1798.3^{\mathrm{abc}}$ \\
Mean & 77.47 & 5.79 & 98.6 & 9096.35 & 1776.58 \\
SE \pm & 2.59 & 0.19 & 0.76 & 325.29 & 86.86 \\
LSD (0.05) & 9.19 & 1.56 & 4.05 & 2367.70 & 606.72 \\
CV (\%) & 5.25 & 11.88 & 1.81 & 11.51 & 15.10 \\
\hline
\end{tabular}

Note: ${ }^{\dagger}$ Means followed by the same letters are not significantly different at $P \leqslant 0.05$.

Table 12.2 Correlation coefficients between traits in food barley varieties

\begin{tabular}{llllll}
\hline Traits & $P H$ & $S L$ & $D M$ & $F B M$ & $Y L D$ \\
\hline PH & 1.00 & 0.04 & 0.12 & 0.20 & $0.52^{\star}$ \\
SL & & 1.00 & 0.23 & 0.03 & 0.10 \\
DM & & 1.00 & -0.11 & -0.30 \\
FBM & & & 1.00 & $0.61 \star \star$ \\
YLD & & & & 1.00 \\
\hline
\end{tabular}

Notes: ${ }^{\star}$ Significant at the 0.05 probability level; ${ }^{\star} \star$ significant at the 0.01 probability level. $\mathrm{PH}$ $=$ Plant height, $\mathrm{SL}=$ Spike length, $\mathrm{DM}=$ Days to maturity, $\mathrm{FBM}=$ fresh above ground biomass, YLD $=$ Grain yield

Farmers selected and ranked food barley varieties based on their selection criteria (see Figure 13.1). Estayish, Misrach, Shediho and HB1307 were the best-performing varieties in farmers' selection. Grain yield, above ground biomass, grain fullness, number of rows/spike, tillering capacity, earliness and disease tolerance were traits by which farmers selected varieties (Table 12.3). Farmers also used non-rachis brittleness as a selection criterion. This trait has the benefit of efficient harvesting without the loss of grains and it was one of the most important traits for the domestication of barley (von Bothmer et al., 2003). Farmers' preference for biomass yield was also high as they feed the straw 
Table 12.3 Farmers' reactions and decisions for food barley varieties

\begin{tabular}{|c|c|c|}
\hline Variety & Evaluation criteria and assessment & Decision \\
\hline Shediho & $\begin{array}{l}\text { Relatively early, good grain size, good biomass, } \\
\text { resists waterlogging }\end{array}$ & Selected third \\
\hline Agegnehu & $\begin{array}{l}\text { Small spike, thin stem, rachis brittleness, poor } \\
\text { biomass }\end{array}$ & Rejected \\
\hline Yedogit & Short, waterlogging susceptible, infected by scald & Rejected \\
\hline Estayish & $\begin{array}{l}\text { Early, large spike, tall, good tillering capacity and } \\
\text { biomass, waterlogging resistant }\end{array}$ & Selected first \\
\hline Misrach & $\begin{array}{l}\text { Early, large spike, tall, high tillering capacity, } \\
\text { good biomass, waterlogging resistant, some } \\
\text { unfilled spikelets }\end{array}$ & Selected second \\
\hline Tila & $\begin{array}{l}\text { Small spike, very short height, susceptible to } \\
\text { waterlogging, very poor tillering }\end{array}$ & Rejected \\
\hline Setegn & Poor tillering, poor biomass & Rejected \\
\hline Bentu & $\begin{array}{l}\text { Mixture, poor tillering capacity, poor biomass, } \\
\text { short }\end{array}$ & Rejected \\
\hline HB1307 & $\begin{array}{l}\text { Medium maturing, good tillering, high biomass, } \\
\text { tall, some sterile spikelets }\end{array}$ & Selected fourth \\
\hline Local & $\begin{array}{l}\text { Late maturing, } 2 \text { rowed spike, prone to bird } \\
\text { damage, lacks uniformity in tillering }\end{array}$ & Rejected \\
\hline
\end{tabular}

and the residue of the crop to their livestock. Farmers also explained that their animals prefer barley straw to that of wheat; therefore they favoured characteristics associated with straw quality (mostly softness and thin stem). These qualities and biomass yield played a major role in the acceptance and adoption of new varieties into the farming community (Traxler and Byerlee, 1993). Earliness of the variety was also one of the farmers' important selection criteria as the seasonal rainfall distribution is very short in the Gumara-Maksegnit watershed area and this enables farmers to achieve a good yield.

The Spearman's rank correlation analysis showed that there was no significant association (at $P=0.05$ ) between farmers' and the researcher's rankings for varieties using grain yield. The non-significant association of the rankings of varieties showed that grain yield was not the only selection criterion for farmers and the rankings of varieties by farmers and the researcher were different. This result might be due to the fact that the ranking of varieties by farmers was based on the yield components and other traits in the field whereas that of the researcher was based on statistical analysis results of grain yield. Ranking of varieties using individual traits could show clearly the relation between the farmers' preferences and the researcher's view across the varieties. Therefore, the best varieties could be identified using the rank sum method. Based on this method, the selected varieties were Estayish, Shediho, Misrach and HB1307 (Table 12.4). 
Table 12.4 Farmers' and researcher's rank and rank sum of varieties based on mean grain yield

\begin{tabular}{lllccc}
\hline Variety & $\begin{array}{l}\text { Grain yield } \\
(\mathrm{kg} / \mathrm{ha})\end{array}$ & $\begin{array}{l}\text { Farmers } \\
\text { rank }\end{array}$ & $\begin{array}{l}\text { Researcher } \\
\text { rank }\end{array}$ & $\begin{array}{l}\text { Rank } \\
\text { sum }\end{array}$ & Rank \\
\hline Shediho & 2045 & 3 & 3 & 6 & 2 \\
Agegnehu & 2098.3 & 7.5 & 2 & 9.5 & 5 \\
Yedogit & 1191.7 & 7.5 & 10 & 17.5 & 10 \\
Estayish & 2380.8 & 1 & 1 & 2 & 1 \\
Misrach & 1722.5 & 2 & 6 & 8 & 3 \\
Tilla & 1532.5 & 7.5 & 8 & 15.5 & 8 \\
Setegn & 1626.7 & 7.5 & 7 & 14.5 & 7 \\
Bentu & 1493.3 & 7.5 & 9 & 16.5 & 9 \\
HB1307 & 1876.7 & 4 & 4 & 8 & 3 \\
Local & 1798.3 & 7.5 & 5 & 12.5 & 6 \\
\hline
\end{tabular}

\section{Conclusion and recommendations}

Food barley varieties showed significant difference for grain yield and other traits. Positive and significant relations were found between grain yield and plant height and between grain yield and biomass yield. The Spearman's rank correlation analysis showed no significant association between the farmers' and the researcher's rankings for varieties, and best varieties were identified using the rank sum method. The non-significant association indicates that grain yield is not the only selection criterion for farmers, and breeders should consider farmers' criteria. Estayish, Shediho, Misrach and HB1307 showed better performance in grain yield and farmers' preferences. Therefore, these varieties are recommended for the upper part of the Gumara-Maksegnit watershed and the supply of quality seeds and scaling-out of these varieties could help to contribute to improved livelihoods in this dry spell watershed area.

\section{References}

Abdollah, H., Saeed, A., Abolghasem, M. and Mehrdad, Y., 2011. 'Survey, correlation of yield and yield components in 40 lines barley (Hordeum vulgare L.) in region Tabriz'. Middle-East Journal of Scientific Research, 10(2): 149-52.

Budakli, C.E. and Celik, N., 2012. 'Correlation and path coefficient analyses of grain yield and yield components in two-rowed of barley (Hordeum vulgare convar. distichon) varieties'. Notulae Scientia Biologicae, 4(2): 128-31.

Central Statistical Agency (CSA), 2007. 'Area and Production of Crops (private peasant holdings, Meher season)'. Agricultural Sample Survey 2006-7, CSA Statistical Bulletin No 388, Addis Ababa, Ethiopia.

Drikvand, R., Samiei, K. and Hossinpor, T., 2011. 'Path coefficient analysis in hull-less barley under rainfed condition'. Australian Journal of Basic and Applied Sciences, 5(12): 277-9.

Harlan, J.R., 1969. 'Ethiopia: a centre of diversity'. Economic Botany, 23: 309-14. 
Mulatu, B. and Lakew, B., 2006. 'Barley research and development in Ethiopia - an overview' in B. Mulatu and S. Grando (eds), Barley Research and Development in Ethiopia (pp. 1-16). Proceedings of the 2nd National Barley Research and Development Review Workshop, 28-30 November 2006, Holetta, Ethiopia. ICARDA, Aleppo, Syria.

SAS Institute (2003). 'SAS Version 9. 1.2 2002-2003'. SAS Institute, Cary, NC.

Traxler, G. and Byerlee, D., 1993. 'A joint-product analysis of the adoption of modern cereal varieties in developing countries'. American Journal of Agricultural Economics, 75: 981-9.

Von Bothmer, R., Sato, K., Kniipffer, H. and van Hintum, T., 2003. 'Barley diversity an introduction' in R. von Bothmer, T. van Hintum, H. Kniipffer and K. Sato (eds), Diversity in Barley (Hordeum vulgare). Elsevier Science, Amsterdam, Netherlands.

Yirga, C., Alemayehu, F. and Sinebo, W. (eds), 1998. Barley-based farming systems in the highlands of Ethiopia. Ethiopian Agricultural Research Organization, Addis Ababa, Ethiopia. 